\title{
A SUBJEETIVE ASSESSMENT OF ACCIDENT RISK IN DOWNHHLL SKIING BY BEGINNER SKIERS AND SKI INSTRUCTORS
}

\author{
Iwona Pawelec \\ PhD Studies, Department of Recreation, University School of Physical Education in Wrocław, Poland \\ Address for coprespondence: \\ Pawelec Iwona \\ Department of Recreation, University School of Physical Education in Wrocław, Poland \\ Al. J.I. Paderewskiego 35, building P4, 51-612 Wrocław, Poland \\ E-mail: iwona.pawelec@onet.pl
}

\begin{abstract}
Ahstract. Nowadays downhill skiing is one of the most popular form of winter recreation. Although skiing fulfills a number of contemporary health and leisure needs, even skiing on very well-prepared terrain poses several dangers and risks. Objective safety would be the state of being protected or free from all danger. The subjective aspect relates to one's mental state and is based on their feeling of confidence of another person, organization, or situation. Subjective risk is connected with perception and is dependent not only on how one perceives a threat but also how can assess its possible outcomes. There are three factors composing the qualitative dimension of risk perception, being 'the fear of risk', 'an unknown risk', and 'the level of risk'. The first factor is associated with such features as worrying about potential consequences, anxiety, negativity, voluntariness, and the ability to manage risk. Data was collected by use of a diagnostic survey designed by the study's author (Risk Assessment Questionnaire). In total, 53 participants completed the survey ( 26 instructors, 27 beginners). Beginner skiers believed there to be a higher level of risk in skiing than ski instructors, especially among aspects that assessed their perception of risk that concerned themselves. Beginner skiers clearly assessed the risk of downhill skiing higher when it concerned their own welfare and declared higher levels of fear of being involved in an accident.
\end{abstract}

Key Worlls: winter recreation, risk, skiing safety, accidents

\section{Introduction}

The obvious benefits of regular outdoor physical activity are improved physical and mental health. Moreover, it enhances one's sense of security by not only producing a general feeling of well-being and improved self-esteem but also through gaining confidence and familiarity with the outdoors (Ambroży, Ambroży, 2000; Gracz, Sankowski, 2001). Nonetheless, outdoor recreation does possess a number of risks, although involvement in all its forms is considered to be a form of conscious and positive risk-taking behavior, one connected with the desire for adventure, testing one's abilities, and taking advantage of the experiences active outdoor activities offer (Gracz, Sankowski, 2001).

One of the most popular outdoor recreational activities both in Poland and the world is skiing. Not only does this winter sport provide a number of clear health benefits but it can be practiced by any age group regardless of 
social status. Rising participant numbers show that more and more people are interested in winter sports (Chojnacki, 2005).

The positives of skiing have been recognized since its early beginnings, with a famous Norwegian skier stating "Nothing else strengthens the muscles, provides greater flexibility, strengthens the will, nor clears the mind than skiing" (Nansen, 1891 in: Krasicki, 2001), words still as current as they were in his time. Besides being an attractive and active form of leisure, skiing's positive contribution to health and well-being also stem from its winter mountain setting (Krasicki, 2001). Recreational skiing helps to release stress and provides enjoyment stemming from the excitement of sliding on snow and the satisfaction one receives from overcoming the technical difficulties inherent in skiing. In addition, it has been linked with improving social contacts and with developing self-awareness and self-control (Gracz, 2013).

Although skiing fulfills a number of contemporary health and leisure needs, even slow skiing on very wellprepared terrain poses several dangers and risks, most in the form of experiencing an accident and, therefore, injury (Chojnacki, 2005). Naturally, the increasing popularity of skiing and the rising number of ski areas have seen a dramatic rise in the number of on-slope injuries. Interdisciplinary research has indicated various reasons for the increase in the number of accidents/injuries, with the literature paying increasingly more attention to the issue of regulating safety. The most commonly cited causes for this increasing trend include changes in skiing technique, the growth of carving, the rising popularity of snowboarding, self-taught mistakes, teaching errors, and failure to follow the Skier Responsibility Code (Chojnacki, 1994).

When considering issues surrounding the concepts of risk and safety in a given physical activity, it is important to define their meaning first as a subject of research and then understanding what assessment criteria are available. Safety is generally the objective condition of being free from any threat or danger, although it may be perceived subjectively by an individual or group. As a result, the concept of safety always needs to be reported in two aspects - the objective and subjective. Objective safety would be the state of being protected or free from all danger. The subjective aspect relates to one's mental state and is based on their feeling of confidence of another person, organization, or situation. It can be expressed by the concept of 'feeling safe', which is connected with one's awareness of the existence of a threat as well as one's knowledge about the specific threat and ways of avoiding it (Korzeniowski, 2008; Janosec, Korzeniowski, 2011).

Although safety is the idea that there is no danger and that the presence of danger creates an unsafe situation, even the presence of a real danger does not necessarily mean that loss, damage, or injury must take place. However, the idea of danger does hold a destructive value, as the recognition of danger can itself potentially cause an unwanted condition. The presence of danger is nonetheless dependent on the specific functions or capabilities of a given object or subject. Dangers that are not intrinsically dangerous must always relate to the given object or subject and on those grounds they can be determined as harmful or destructive. In this regard, every object or subject has certain weaknesses that can transform a potential danger into an injury.

This needs mention, as risk, in turn, is defined as the expectation of loss or danger that takes into account both the amount of damage that could occur but also the likelihood of it occurring (Gasparski, 2003; Makarowski, 2008). It is nonetheless a very ambiguous word and can be defined in different ways depending on which scientific approach, and its theoretical basis, is adopted. The lack of homogeneity in defining risk allows it to be studied in various contexts; it can be treated as danger, uncertainty, chance, the probability of a loss or gain, the weighted sum of some negative consequences, or a combination or all of the above factors (Makarowski, 2010). The general 
understanding of risk is perceived as the possibility or probability that something will not succeed or an activity that can threaten something of value (Szymczak, 1981; Kurcz, Skarżyńska, 2000). Regardless of the different concepts of risk, the chance of loss, injury, or an unwanted situation is a common feature. Psychology treats the acknowledgment of risk are being based on previous experience, an individual must have had a previous situation where certain feelings were accompanied by the introduction of given stimuli. It is in this way they inform a person about the risk itself and what kind of complications may occur. Perceiving risk requires a single, coherent, and subjective image of oneself, or any other persons, and their relation to a danger. This image affects our preferences and choices in decision-making situations (Studenski, 2004).

In the literature, psychological work has three types of definitions for the concept of risk. Risk, understood as the uncertainty of one's own actions and their consequences in the presence of random/uncontrollable factors or cognitive limitations, has a person act in conditions unknown and obscure to them. Second, risk is associated with the consequences of a conscious decision that may feature potential loss or danger, made by cognitively balancing the positive and negative outcomes of one's own actions. The next definition defined risk as an action performed by a person that has an unknown, uncertain, and possibly problematic result that exposes one to danger, damage, or loss (Makarowski, 2010).

Every person, and therefore every skier, has two roles when it comes to a situation involving risk when skiing, where they may be the subject or object of risk. Regardless of this duality, the basis behind taking a risky decision involves consequences that are likely to end in loss or damage. The negative consequences of one's own or someone else's actions can be either direct or indirect (Ratajczak, 2004).

One of the primary risk classification systems assumes that there is both subjective and objective risk in a given situation. Subjective risk is connected with perception and is dependent not only on how one perceives a threat but also how can assess its possible outcomes. Objective risk involves the aspect of risk that can be statistically analyzed (Makarowski, 2010). In this way, the perception of risk may be assessed by numerous quantifiable factor including the probability of a loss, the size of the loss, the expected loss, the expected variance if a loss may occur or not, and linear relationship between the hoped for result and possible variance. In this case, risk is perceived as being higher when the type of loss or the probability of it occurring is higher. Expected loss, in turn, is the sum of all the expected negative outcomes weighted by the probability of them occurring. The above dimensions of risk help to illustrate the mathematical approach to calculating risk, which can help to determine which choice would be the most rational.

However, the use of such standardized dimensions of risk is rarely used by people, as risk is perceived by conditioned physiological and emotional processes (Zaleśkiewicz, 2005). Risk perception in this case is the result of cognitive, emotional, and personality-based determinants reflected in the model created by Rudiger Trimpop. It involves a relationship between individual factors and situational factors. Among the most significant situational factors is the type of activity being performed. Risk perception here includes the perceptions of one's emotional and physiological symptoms and a cognitive assessment of risk, with this last factor based on components such as one's education, skills, experience, and ability to draw conclusions based on the experiences of others (Zaleśkiewicz, 2005; Makarowski, 2010).

There is also brought to light three factors composing the qualitative dimension of risk perception, being 'the fear of risk', 'an unknown risk', and 'the level of risk'. The first factor is associated with such features as worrying about potential consequences, anxiety, negativity, voluntariness, and the ability to manage risk. This factor is most 
strongly correlated with a direct assessment of an activity's riskiness. Second, 'an unknown risk' refers to concepts such as if the risk had ever been experienced before, what is known about it, and what consequences may emerge later in time. Its nature is grounded in the fact that a person may be aware that a risk exists but is unable to precisely define the risk in question due to confusion or a lack of information surrounding it. The last factor is related to the number of individuals likely to be exposed to a given danger. The more people that can concurrently experience the negative effects of a given risk, the higher the risk is assessed. The structure of these factors is considered to be universal, meaning that they affect risk assessment regardless of who assesses the risk or the type of activity being evaluated (Slovic in: Sokołowska, 2000).

In light of the above, the aim of this study was to research subjective risk in downhill skiing and to search for differences in the level of risk assessment by beginners and expert-level skiers. With this in mind, the following research questions were formulated:

1. How is risk assessed by beginner and expert skiers?

2. Does experience and skill level determine risk assessment in downhill skiing?

\section{Methods}

Data was collected by use of a diagnostic survey designed by the study's author. Titled the Risk Assessment Questionnaire, it evaluates how the risk of accident is assessed in recreational skiing. The questionnaire consists of 17 items ( 15 closed-and 2 open-ended) which assess the qualitative dimension of risk assessment, with respondents specifying what they feel to be the level of risk in skiing, the voluntariness of risk, the ability to manage risk, the level of fear of being involved in an accident, what may be the injury-related consequences of an accident, and what they felt to be the percentage of people at risk of an accident when sking. The close-ended items of the questionnaire were rated using various scales, whereas the open-ended portions asked about the years and number of days per season involved in skiing and if the participant had ever been involved/witnessed an accident. Three closed-ended questions assessed the level of risk or the level of fear in skiing using an ordered scale from 1 to 7 , with 1 being the lowest and 7 the highest level of risk/fear. Items measuring the voluntariness of risk and management of risk when skiing used a 7-point Likert scale, with respondents specifying their level of agreement from 'definitely yes' to 'definitely no'. The part of the questionnaire that assessed what the potential consequences of an accident could be was evaluated using the International Commission for Alpine Rescue's Injury Scale (IKAR-CISA). Respondents had to estimate the probability of various injuries occurring as a result of a skiing accident, ranking its probability between 3.5 and 35 , with 3.5 indicating the least risk whereas 35 the highest amount of risk.

In total, 53 participants completed the survey. The sample was selected by opportunity sampling of individuals based on their skiing experience, targeting expert or beginner skiers. The first group consisted entirely of qualified ski instructors ( $n=26,13$ males and 13 females, mean age 25 years) of which 20 were certified Polish Ski Association (PSA) instructors, five were PSA assistant instructors, and one was a recreation instructor with a specialization in downhill skiing. The second group ( $n=27,4$ males and 23 females, mean age 21 years) was composed of university students majoring in Tourism and Recreation taking skiing lessons as part of their coursework. The skiing experience of the groups showed that the instructors had been practicing skiing for more than 10 years, spending an average 45 days per season on the slope. In the beginners group, 24 respondents had been skiing for less than 
1 year, two had been involved in the sport from 4 to 6 years, and one for more than 10 years. The average number of days spent on the slope was 6 for this group.

\section{Results}

The basic characteristics of the respondents are presented in Table 1.

Table 1. Characteristic of the respondents

\begin{tabular}{llcc}
\cline { 3 - 4 } & & Ski instructors & Beginner skiers \\
\hline Sex & women & 13 & 23 \\
& men & 13 & 4 \\
\hline Avarage age & & 25 & 21 \\
\hline Education & university & 11 & 3 \\
& secondary & 15 & 24 \\
\hline
\end{tabular}

The beginners group achieved higher mean scores than the instructors for the items assessing the level of accident risk for the average skier and for themselves, the fear of being involved in an accident, and the ability to manage risk when skiing (Figure 1), although statistically significant differences were found only for fear of being involved in an accident $(p=0.006)$ and the level of risk only in regards to their own welfare $(p=0.013)$. Here, the potential risk of an accident directly involving the respondent was assessed as 1 by $11.5 \%, 2$ by $23.1 \%$, and 3 by $19.2 \%$ of the instructors (Figure 2). Among the beginners, the majority evaluated the risk of an accident occurring as 4 by $37 \%, 5$ by $29.6 \%$, and then 3 by $22.3 \%$.

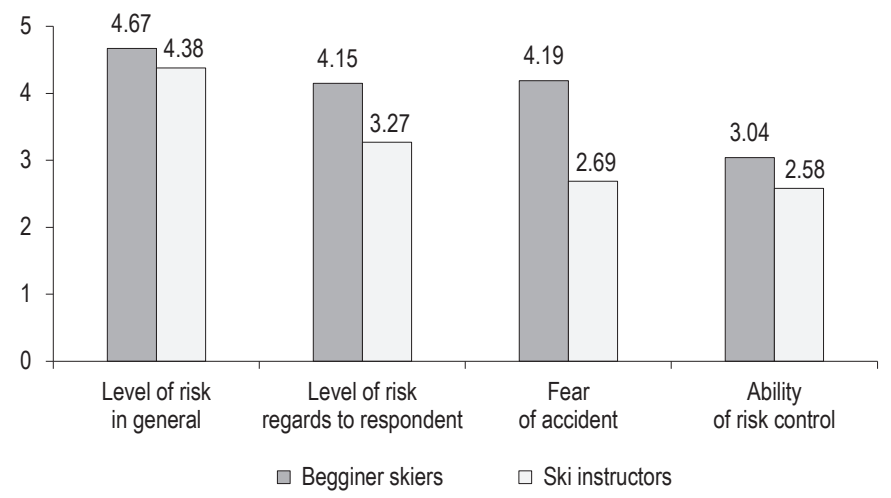

Figulp 1. The dimensions of risk perception 


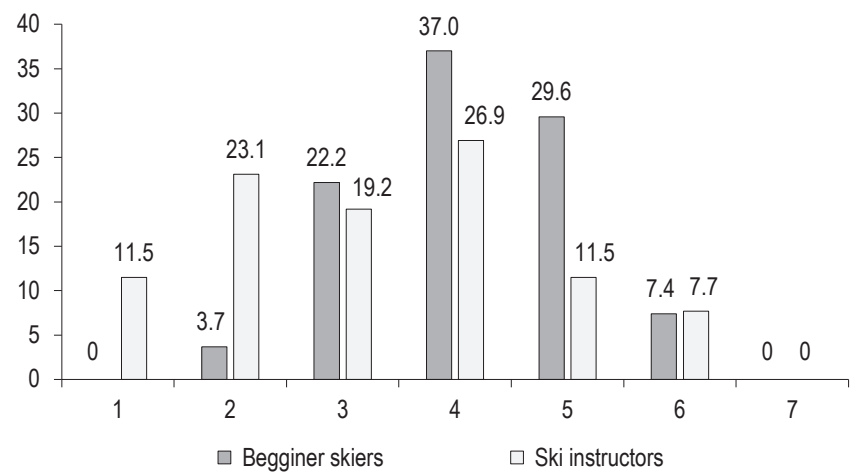

Figure 2. The percentage distribution of the assessment of risk of accident in regards to the respondents

The percentage distribution of the responses to fear of an accident directly involving them is presented in Figure 3, where the largest percentage of expert skiers (42.3\%) indicated a response of 2 . Among the beginners, this was assessed as 4 by $25.9 \%$ of the group.

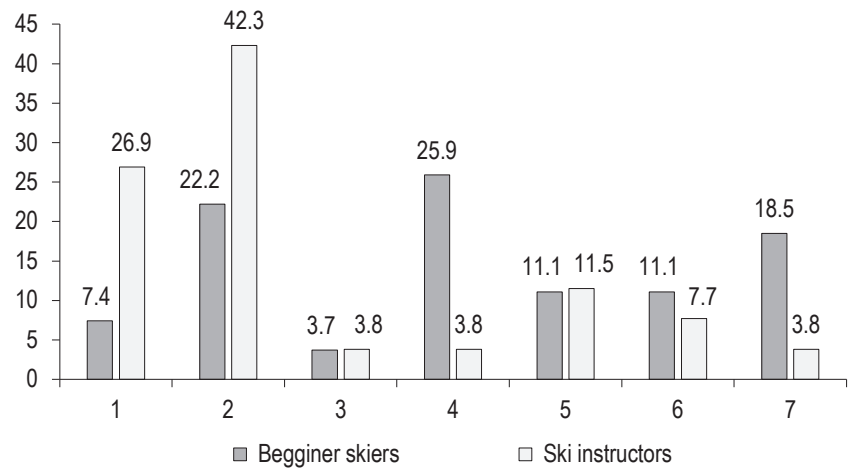

Figure 3. The percentage distribution of the responses regarding fear of accident

The ability to gauge what consequences may arise after a skiing accident (probability of a specific injury) was evaluated by the respondents in reference to the average skier and themselves, i.e. what injuries they felt they were likely to suffer. The beginner group assessed the risk of injury higher than the expert skiers, with the largest difference between the two groups in assessing those injuries that may affect the average skier, with beginners obtaining a mean score of 10.41 and experts 7.72 . When assessing the risk of personal injury, beginners scored 8.20 and the instructors 7.77 (Figure 4). 


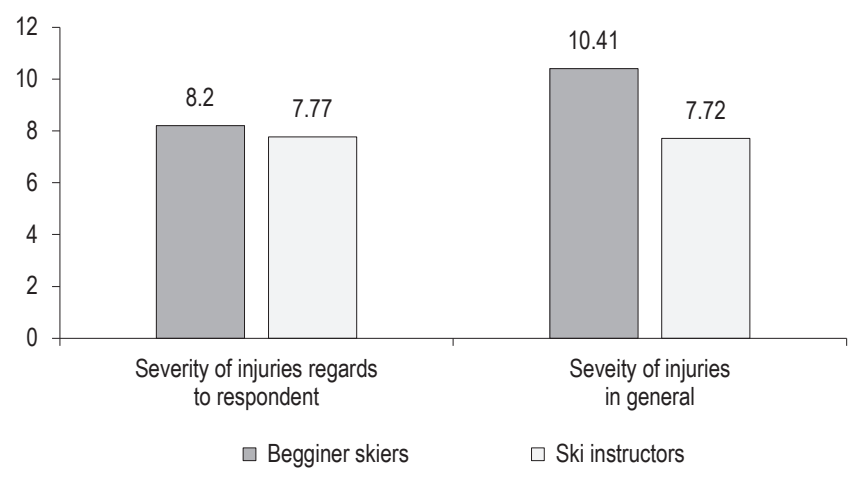

Figulp 4. Severity of injuries assessed by respondents

The overall score of assessing risk for beginners was 9.53 and 7.36 for experts, with the difference between the two at the limit of statistical significance $(p=0.05)$.

The responses on the participants' involvement in a skiing accident was then compared with their estimate of the number of people involved in an accident when skiing. Here, $73.1 \%$ of the expert skiers had witnessed an accident and $50 \%$ had been involved in one. Among the beginners, $77.8 \%$ reported they had witnessed an accident, but only $25.9 \%$ had been involved in one. However, beginner skiers assessed the percentage of average skiers who had been in an accident to be $34.3 \%$, while the expert group assessed this to be $24 \%$ of all skiers (Table 2).

Table 2. The percentage of skiers involved in accidents estimated by respondents and experiences of them

\begin{tabular}{lcc}
\cline { 2 - 3 } & Ski instructors & Beginner skiers \\
\hline The percentage of skiers involved in accident estimated by respondents & 24.0 & 34.3 \\
The percentage of accidents' witnesses & 73.1 & 77.8 \\
The percentage of respondents involved in accidents & 50.0 & 25.9 \\
\hline
\end{tabular}

\section{Discussion}

Risk is present in every physical activity, subject to a wide gamut of factors. However, the complexity of assessing risk makes it a very difficult concept to define. Nonetheless, further understanding of the perception and internal mechanisms of risk is particularly important due to the growing popularity of recreational sports, as many participants do not only lack general knowledge about the sport they are practicing, but have little methodologicaltechnical understanding or interaction with professional advice and coaching (Gracz, Sankowski, 2001; Merski, Warecka, 2001).

Research on people's personal experience and observations and the assessments they make on the likelihood of risks found that both the experiences that affect us directly and the observations we make of a situation that poses a risk to other individuals all have an impact on our cognitive schemas. This in particular involves the schema associated with anticipating a future threat that may endanger our safety. In this way does experience with 
threats influences our assessment of risk. In contrast, whether a person will protect themselves against a threat is determined by whether they perceive the threat as one that can endanger them personally. However, experience based on previous encounters or observations of risky situations increases the likelihood of determining a future threat, which can be considered to be a form of preventive action.

A similar effect on risk assessment was found in the case of personal contact or observation of a dangerous situation involving other individuals (Gasparski, 2004). Such a correlation was observed when comparing the subjective assessment of risk by recreational downhill and cross-country skiers. In this study, the cross-country skiers had been involved in more accidents and, at the same time, estimated that a higher percentage of people suffer from an accident while skiing in open mountainous country (Pawelec, 2014). However, the results of the present study do not allow for the conclusion that personal experience with an accident is associated with a higher level of subjectively assessed risk. In the group of expert skiers, of whom half had been involved in an accident, the estimated percentage of skiers involved in an accident was lower than that reported by the beginner group, whom had less individuals involved in an accident (Table 2).

\section{Conclusions}

Beginner skiers believed there to be a higher level of risk in skiing than ski instructors, especially among aspects that assessed their perception of risk that concerned themselves. Previous experience was found to affect the subjective perception of risk only in some of the analyzed dimensions. Beginner skiers clearly assessed the risk of downhill skiing higher when it concerned their own welfare and declared higher levels of fear of being involved in an accident.

Bearing in mind that skiers themselves and their behavior are largely responsible for their own personal safety when skiing, further research should aim to clarify the relationship between objective risk and the subjective aspects surrounding risk assessment. A feature undoubtedly of importance would be the dependencies between individuals involved in various recreational activities and their propensity to engage in risky behavior. This would involve analyzing the determinants of their assessment of risk including factors such as previous experience, age, or knowledge of a particular risk.

\section{References}

Ambroży, D., Ambroży, T. (2000). Aktywność fizyczna człowieka jako realizacja potrzeby bezpieczeństwa. In: P. Tyrała (ed.), Zarządzanie bezpieczeństwem (pp. 135-137). Międzynarodowa Konferencja Naukowa, 11-13. Maja 2000. Kraków: Wydawnictwo Profesjonalnej Szkoły Biznesu.

Chojnacki, K. (1994). Studium epidemiologiczne urazowości a zagrożenie wypadkowe w narciarstwie zjazdowym. Kraków: Akademia Wychowania Fizycznego im. Bronisława Czecha.

Gasparski, P. (2003). Psychologiczne wyznaczniki gotowości zapobiegania zagrożeniom. Warszawa.

Gasparski, P. (2004). Związek doświadczeń z ocenami prawdopodobieństwa zagrożeń i aktywnością profilaktyczną. In: R. Studenski (ed.), Zachowanie się w sytuacji ryzyka (pp. 149-161). Katowice: Uniwersytet Śląski.

Gracz, J., Sankowski, T. (2001). Psychologia w turystyce i rekreacji. Poznań: Akademia Wychowania Fizycznego im. E. Piaseckiego. Janosec, J., Korzeniowski, L.F. (2011). Nauki o bezpieczeństwie. Kraków.

Korzeniowski, L.F. (2008). Securitologia. Kraków.

Krasicki, S. (2001). Narciarstwo jako jeden ze sportów całego życia In: S. Krasicki, K. Chojnacki (eds.), Sporty zimowe u progu XXI wieku oraz tradycje i perspektywy Zakopanego (pp. 43-46). Kraków: Akademia Wychowania Fizycznego w Krakowie. 
Makarowski, R. (2008). Granice ryzyka. Paradygmat psychologiczny. Kraków: Oficyna Wydawnicza „Impuls”.

Makarowski, R. (2010). Ryzyko i stres w lotnictwie sportowym. Warszawa: Difin.

Merski, J., Warecka, J. (2009). Główne przyczyny nieszczęśliwych wypadków i zachorowań podczas imprez turystycznych In: J. Merski, J. Warecka (eds.), Turystyka kwalifikowana. Turystyka aktywna. Warszawa: ALMAMER.

Pawelec, I. (2013). Risk taking propensity among people involved in various forms of winter recreation on the example of skiing. Centr Eur J Sport Sci Med, 2, 39-47.

Ratajczak, Z. (2004). Kontrowersje wokół pojęcia ryzyka. In: R. Studenski (ed.), Zachowanie się w sytuacji ryzyka (pp. 13-20). Katowice: Uniwersytet Śląski.

Sokołowska, J., (2000). Ryzyko: wyzwanie czy zagrożenie. Psychologiczne modele oceny i akceptacji ryzyka. Warszawa: Instytut Psychologii PAN.

Studenski, R. (2004). Ryzyko i ryzykowanie. Katowice: Uniwersytet Śląski.

Szymczak, M. (1981). Słownik języka polskiego. Warszawa: Państwowe Wydawnictwo Naukowe.

Zaleśkiewicz, T. (2005). Przyjemność czy konieczność. Psychologia spostrzegania i podejmowania ryzyka. Gdańsk: Gdańskie Wydawnictwo Psychologiczne.

Cite this article aS: Pawelec, I. (2016). A subjective Assessment of Accident Risk in Downhill Skiing by Beginner Skiers and Ski Instructors. Central European Journal of Sport Sciences and Medicine, 13 (1), 143-151. DOI: 10.18276/cej.2016.1-14. 
